\title{
Computational Approach to Evaluate Eugenol Affinity and Derivatives Empirical Against $\mathrm{Cu}$ (II)
}

\author{
Muhammad Cholid Diunaidi ${ }^{*}$, Tantri Nevi Astuti ${ }^{1}$, Parsaoran Siahaan ${ }^{1}$ \\ ${ }^{1}$ Chemistry Department, Faculty of Natural Sciences and Mathematics, Diponegoro University \\ Jl. Prof. Soedarto, Tembalang, Semarang, Indonesia
}

*Corresponding author email: muhammadcholiddjunaidi@gmail.com

Received March 6, 2019; Accepted October 10, 2019; Available online November 30, 2019

\begin{abstract}
A computational approach to assess the emperical results of eugenol affinity, eugenoxy acetate (EOA), and pyridine methyl eugenoxy acetate (PMEOA) against $\mathrm{Cu}^{2+}$ has been done. This research aims to determine the effects of the functional groups $(-\mathrm{OH},-\mathrm{COOH}$, and $-\mathrm{N})$ on eugenol and their derivatives on the selectivity of $\mathrm{Cu}^{2+}$ adsorption experimentally and to calculate the energy interaction between eugenol compounds and derivatives with $\mathrm{Cu}^{2+}$. The experimental approach was carried out by solvent extraction method, using $10 \mathrm{~mL}$ of $\mathrm{Cu}^{2+} 10$ ppm solution along with 0.3089 $\mathrm{mmol}$ of eugenol, EOA and PMEOA. The remaining concentration of $\mathrm{Cu}^{2+}$ metal after extraction in the water phase was measured using an Atomic Absorption Spectrophotometer (AAS). Assessments of the $\mathrm{Cu}^{2+}$ metal interaction with eugenol, EOA and PMEOA compounds were carried out using the ab initio method with 6-31 $\mathrm{G}^{* *}$ basis set to predict the interaction energy. The results showed that pyridine methyl eugenoxy acetate (PMEOA) can separate $\mathrm{Cu}^{2+}$ better than eugenol and EOA with extraction efficiency $(\% \mathrm{E})=78.76 \%$. The calculation results of $\mathrm{Cu}^{2+}$ metal interactions with eugenol, EOA, and PMEOA compounds found that PMEOA has the lowest energy of interaction compared to eugenol and EOA with $\mathrm{Cu}^{2+}$ metal.
\end{abstract}

Keywords: Eugenol, Eugenol Derivatives, AAS, Ab Initio, affinity, $\mathrm{Cu}^{2+}$, solvent extraction

\section{INTRODUCTION}

The industry is currently experiencing very rapid development. However, the result of the rapid development of the industry is the production of waste in the form of solid, liquid and gas wastes which result in environmental pollution. Liquid waste in the industry has a role in the release of heavy metals into the water flow. This creates a negative impact on living things in the environment. One of the heavy metals that can pollute the environment is Cu. Metal Cu above the permitted threshold will cause poisoning to living things, especially in humans, potentially causing death. Therefore, it is necessary to tackle pollution caused by Cu metal. Efforts to control and process heavy metal waste are developing, leading to the searches for new methods that are cheap, effective and efficient (Kundari \& Slamet, 2008).

A method that can be used to process heavy metal waste is liquid-liquid extraction. Extraction is highly significant in selective metal separation techniques in industrial waste treatment processes (Khoutoul et al., 2016). Liquid-liquid extraction is the commended technique to recover metals (Hamzah et al., 2011). Moreover, the chosen extraction method has advantages in its use as it does not require expensive and complicated equipment (Harimu, Matsjeh, Siswanta, \& Santosa, 2009). The basic principle of liquid-liquid extraction involves contacting a solution with other solvents that are not immiscible with the original solvent with different density so that it will form two phases shortly after the solvents are combined (Mirwan \& Wicakso, 2008)

The latest development of extraction separation method tends to increase selectivity to certain metals by finding new ligands as extractants through compound synthesis (Kakoi et al., 1998). One of the raw materials that can be used is eugenol. Eugenol is a natural component found in essential oils, including cloves. The content of eugenol in cloves ranges from $60-90 \%$ (Sneddon, 1997). Eugenol is an Indonesian natural ingredient that can be used for the separation of metal ions (Djunaidi, Jumina, Siswanta, \& Ulbricht, 2015; Diunaidi, Siswanta, \& Jumina, 2015). Eugenol is used as a starting material for the synthesis of a compound because there are three functional groups that are bound to it, namely the allyl, hydroxyl and methoxy groups that can potentially work as functional monomers for the selective adsorption process of $\mathrm{Cu}$ (Diunaidi, Wibawa, \& Murti, 2018). With these three active groups, eugenol can function as a carrier 
through a hydroxyl group where eugenol can be entered into a more selective functional group. To increase the selectivity of eugenol, modification was carried out to improve the selectivity of eugenol (Diunaidi, Khabibi, \& Khrisna, 2010). In this study, modification was done by synthesizing eugenol derivatives in the form of eugenoxy acetic acid (EOA) and pyridine methyl eugenoxy acetate (PMEOA).

In addition to the synthesis of eugenol derivatives, this study also aims to study the interaction of $\mathrm{Cu}^{2+}$ with eugenol, EOA, and PMEOA molecules, calculate the interaction energy between eugenol compounds and eugenol derivatives with the most stable $\mathrm{Cu}^{2+}$ in silico. The experimental approach is carried out by solvent extraction methods. The concentration of $\mathrm{Cu}^{2+}$ metal remaining after extraction in the liquid phase was measured using Atomic Absorption Spectrophotometer (AAS). Evaluation of the interactions of $\mathrm{Cu}^{2+}$ metal with eugenol, EOA, and PMEOA compounds were carried out using the ab initio method with basis set 6-31G ** to predict the interaction energy. Through the ab initio method in this study, computational prediction of the interactions can be found and compared to existing theories and experimental results.

\section{EXPERIMENTAL SECTION \\ Materials}

Eugenol pa (SIGMA Aldrich), technical grade $\mathrm{Na}_{2} \mathrm{SO}_{4}$ (Merck), $\mathrm{HCl}$ (Merck), $\mathrm{NaHCO}_{3}$ (Merck), $\mathrm{NaOH}$ pa (Merck), $\mathrm{ClCH}_{2} \mathrm{COOH}$ pa (Merck), Chloroform pa (Merck), Aqua Bidest, $\mathrm{Cu}\left(\mathrm{NO}_{3}\right)_{2}$ (Merck), 2- Pyridinemethanol pa (SIGMA Aldrich), Thionyl Chloride pa (Merck).

\section{Instruments}

Laboratory glassware, reflux equipment, analytical balance sheet (Mettler-200), magnetic stirrer, hotplate stirrer, spatula, $\mathrm{pH}$ meter, fine filtering paper, AAS (Perkin Elmer), FTIR (8201PC Shimadzu), a set of computers with Linux and Windows OS, Notepad ++ software, Chemcraft Software, and Nwchem 6.3 software.

\section{Methodology \\ Eugenoxy Acetic Acid Synthesis}

Five grams of eugenol were put into a $100 \mathrm{~mL}$ boiling flask and was added with $17.5 \mathrm{~mL}$ of $33 \%$ $\mathrm{NaOH}$ solution. The mixture was stirred for 30 minutes. Then $12.5 \mathrm{~mL}$ of $50 \%$ chloroacetic acid solution was added gradually using a dropping pipette while it continued to be stirred. The mixture was heated in a water bath at a temperature of $80-90{ }^{\circ} \mathrm{C}$. Heating was carried out for 2 hours and the process proceeded to cooling and acidification using $6 \mathrm{M} \mathrm{HCl}$ to obtain $\mathrm{pH}=1$. The next stage was extraction using $50 \mathrm{~mL}$ diethyleter with 2 repetitions. The ether extracted was combined and extracted again using sodium bicarbonate $5 \% \mathrm{~b} / \mathrm{v}$ as much as $30 \mathrm{~mL}$ with 3 repetition. The layer of water was then acidified with 6 $\mathrm{M} \mathrm{HCl}$ to attain $\mathrm{pH}=1$. Filtering, drying, and weighing were carried out. The results obtained were analyzed using FTIR.

\section{Pyridine Methyl Eugenoxy Acetate Synthesis}

A total of $3 \mathrm{~g}(0.0135 \mathrm{~mol})$ of eugenoxy acetic acid (EOA) was put into a $100 \mathrm{~mL}$ boiling flask. The EOA was added with $1.6 \mathrm{~mL}(2.624 \mathrm{~g}, 0.022 \mathrm{~mol})$ thionyl chloride dropwise. Then the mixture was refluxed for 150 minutes in a warm cooking oil bath $\left(40{ }^{\circ} \mathrm{C}\right)$, and then cooled. Into the mixture $2 \mathrm{~mL}(2.262 \mathrm{~g}, 0.0207$ mol) of pyridylcarbinol was added dropwise and refluxed again in warm cooking oil $\left(40{ }^{\circ} \mathrm{C}\right)$ for 60 minutes. After it had cooled the result obtained was dissolved in chloroform and washed with water. The extraction result was dried with sodium sulfate anhydride, filtered and then evaporated to remove the remaining solvent. Furthermore, the results were analyzed using FTIR.

\section{Liquid-liquid Extraction}

A sample with a concentration of $0.000638 \mathrm{~mol}$ was dissolved in $10 \mathrm{~mL}$ of chloroform and extracted with $10 \mathrm{~mL}$ of $10 \mathrm{ppm} \mathrm{Cu}$ (II) ion for 3 hours. The mixture was separated and the $\mathrm{Cu}$ (II) concentration in the filtrate was analyzed using AAS twice.

\section{Computational Method}

Nwchem 6.3 program was used for all ab initio molecular orbital and self-consistent field calculations. The geometry of eugenol, EOA and PMEOA, and $\mathrm{Cu}^{2+}$ metal ions were optimized at the 6-31G** basis set. The energy of intermolecular interactions of molecules was also calculated by the SCF method with the same basis for the ab initio calculation.

\section{RESULTS AND DISCUSSION Eugenoxy Acetic Acid (EOA) Synthesis}

The results of the analysis using an infrared spectrometer were obtained according to Figure 1. The presence of absorption bands at 3400 and $3500 \mathrm{~cm}^{-1}$ indicate the presence of $-\mathrm{OH}$ groups in carboxylic acids. Absorption bands in the range $3100-3000 \mathrm{~cm}^{-1}$ are $\mathrm{C}-\mathrm{H}$ sp bands, the range $1600-1475 \mathrm{~cm}^{-1}$ is vibrations of $\mathrm{C}=\mathrm{C}$ from the aromatic ring and the range $800-900 \mathrm{~cm}^{-1}$ indicates that the aromatic is substituted. Uptake at $1635 \mathrm{~cm}^{-1}, 997 \mathrm{~cm}^{-1}$, and 915 $\mathrm{cm}^{-1}$ are the absorption of vinyl groups $(\mathrm{RHC}=\mathrm{CH})$. Acid carbonyl groups are shown in absorption at $1728.22 \mathrm{~cm}^{-1}$. 


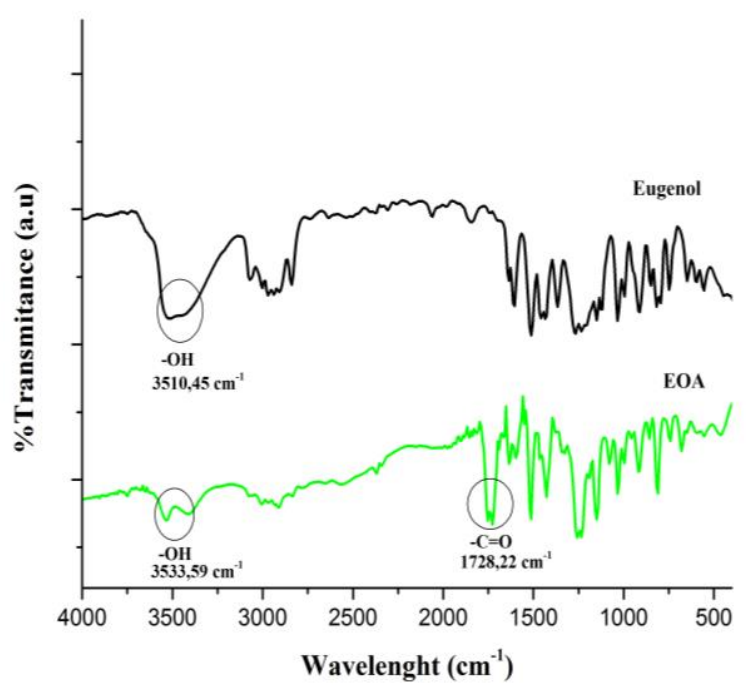

Figure 1. FTIR Spectra of Eugenol and EOA

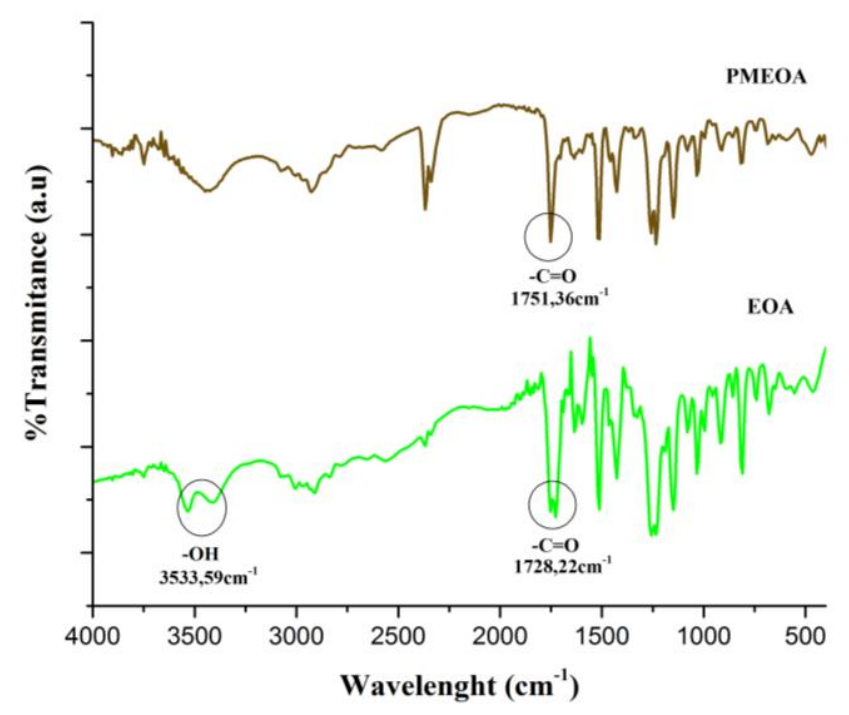

Figure 2. FTIR Spectra of EOA and PMEOA

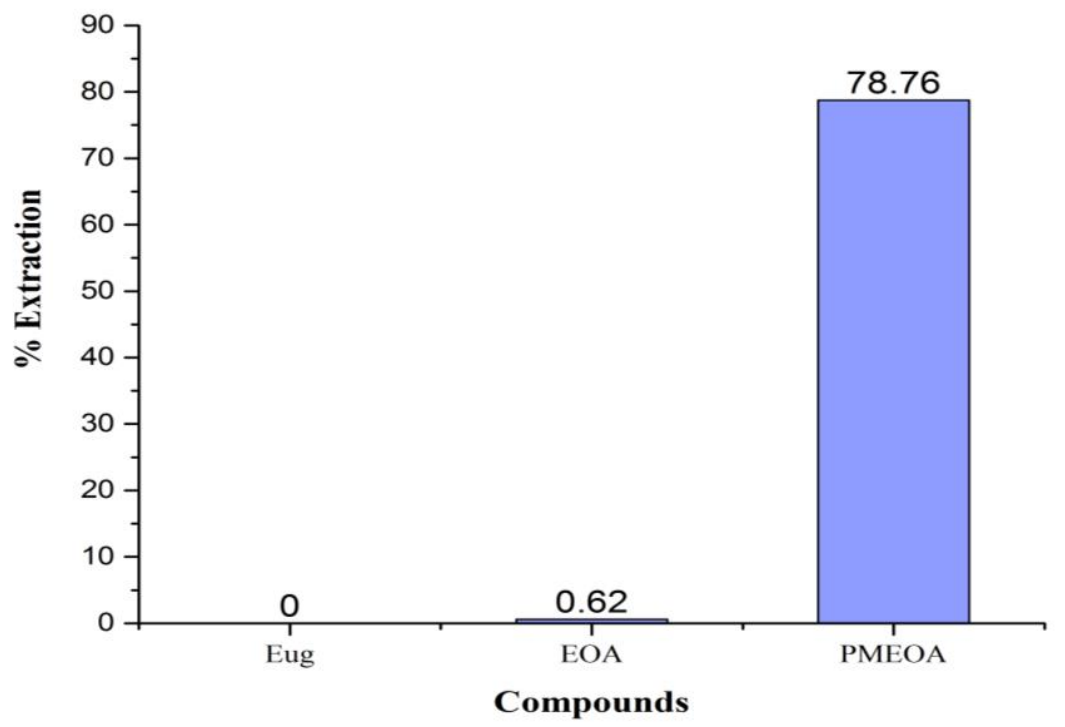

Figure 3. Results of $\mathrm{Cu}^{2+}$ metal \% Extracted in Eugenol, EOA, and PMEOA

EOA was purified by extraction using diethyleter to remove polar impurities along with extraction using $\mathrm{NaHCO}_{3}$ to remove nonpolar impurities. The synthesized EOA has a yield of $75.73 \%$, in the form of a brownish white precipitate and has a melting point of $88-93{ }^{\circ} \mathrm{C}$. The results of the EOA synthesis produced are in accordance with previous studies (Diunaidi et al., 2010).

\section{Pyridine Methyl Eugenoxy Acetate (PMEOA) Synthesis}

PMEOA was obtained from EOA basedsynthesis. The results of PMEOA synthesis can be seen from the results of the following FTIR analysis, Figure 2. The formation of ester can be identified from the infrared spectra at wave number $1751,36 \mathrm{~cm}^{-1}$ which is a spectrum of the carbonyl ester group. Another proof of the formation of esters is the loss of characteristic spectra of the $-\mathrm{OH}$ group or hydrogen bonds which form a wide band at a wavenumber of about $3500 \mathrm{~cm}^{-}$ 1 (Djunaidi et al., 2018). The experiment obtained PMEOA with a yield of $75,73 \%$.

\section{$\mathrm{Cu}^{2+}$ Metal Extraction Results}

From the experimental outcome obtained, \%extracted results are shown in Figure 3 . Based on Figure 3 above, it appears that the percentage of $\mathrm{Cu}(\mathrm{II})$ 
metal ions extracted was highest in PMEOA, followed by EOA and last, eugenol. This is in accordance with the HSAB (Hard Soft Acid Base) theory that says hard acid metals bind more strongly with hard bases, soft acids with soft bases, and borderline acids with borderline bases. $\mathrm{Cu}(\mathrm{II})$ is a borderline acid metal ion so that it can bind to the $\mathrm{N}$-active ligand which is a stronger borderline base than other metal ions (Ho, 1975).

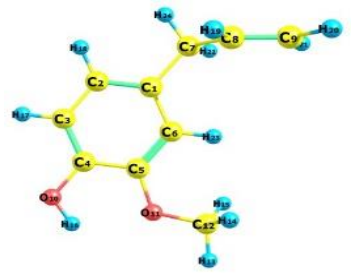

(a)

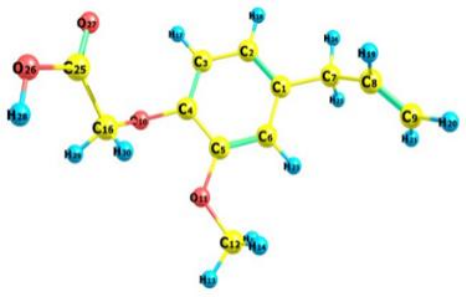

(b)

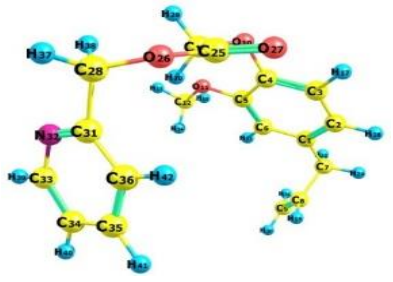

(c)

\section{$\mathrm{H} \odot \mathrm{C} \odot \mathrm{O} \odot \mathrm{N} \odot \mathrm{Cu}$}

Figure 4. (a) Optimized Geometry of Eugenol (b) Eugenoxy Acetate (EOA) (c) Pyridine Methyl Eugenoxy Acetate

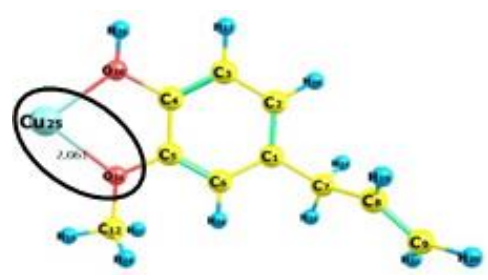

(a)

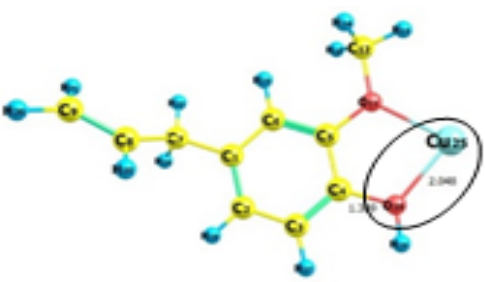

(b)

\section{$\mathrm{H} \odot \mathrm{C} \odot \mathrm{O} \odot \mathrm{N} \odot \mathrm{Cu}$}

Figure 5. Optimized Geometry of interaction between Eugenol and ... $\mathrm{Cu}^{2+}$ (a) Eugenol $\mathrm{O}_{10}$ atom ... $\mathrm{Cu}^{2+}(\mathbf{b})$ Eugenol $\mathrm{O}_{11}$ atom .... $\mathrm{Cu}^{2+}$

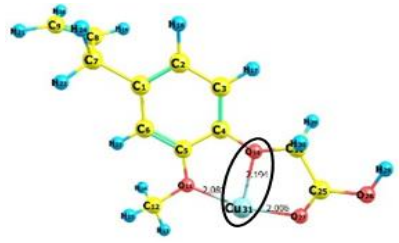

(a)

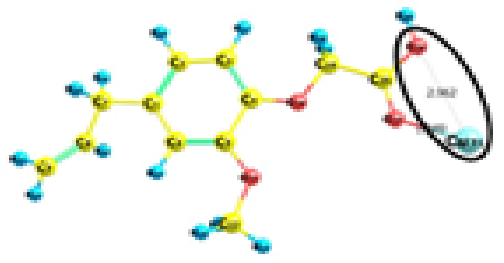

(c)

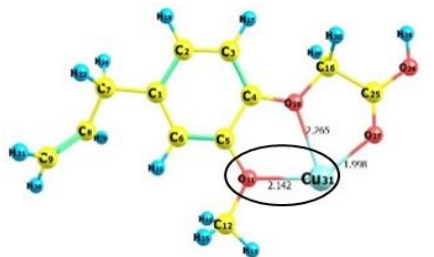

(b)

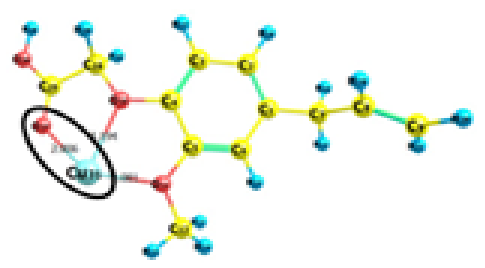

(d)

$\mathrm{H} \odot \mathrm{C} \odot \mathrm{O} \odot \mathrm{N} \odot \mathrm{Cu}$

Figure 6. Geometry optimization of eugenoxy acetate $(E O A)$ that has interacted with $\mathrm{Cu}^{2+}\left(\right.$ a) $\mathrm{EOA} \mathrm{O}_{10}$ atom $\mathrm{Cu}^{2+}$ (b) $\mathrm{EOA} \mathrm{O}_{11}$ atom... $\mathrm{Cu}^{2+}$ (c) $\mathrm{EOA} \mathrm{O}_{26}$ atom... $\mathrm{Cu}^{2+}$ (d) $\mathrm{EOA} \mathrm{O}_{27}$ atom... Cu $\mathrm{Cu}^{2+}$ 


\section{Computational Study}

In this study, $\mathrm{Cu}^{2+}$ was exposed and interacted with eugenol, EOA, and PMEOA molecules. The atoms that interacted with $\mathrm{Cu}^{2+}$ in eugenol were $\mathrm{O}_{10}$ and $\mathrm{O}_{11}$, in EOA were $\mathrm{O}_{10}, \mathrm{O}_{11}, \mathrm{O}_{26}$ and $\mathrm{O}_{27}$ whereas in PMEOA were $\mathrm{O}_{10}, \mathrm{O}_{11}, \mathrm{O}_{26}, \mathrm{O}_{27}$, and $\mathrm{N}_{32}$ atoms. The results of geometry optimization show that there are interactions between $\mathrm{Cu}^{2+}$ with eugenol, EOA and PMEOA, Figure 4. and Table 1, which were indicated by changes in distance, angle, and dihedral in each molecule shown in Table 2.

The interactions were carried out at the positions of the eugenol $\mathrm{O}_{10}$ atom ... $\mathrm{Cu}^{2+}$ and eugenol $\mathrm{O}_{11}$ atom $\ldots \mathrm{Cu}^{2+}$ which produced interaction energies that are not much different, specifically $\mathrm{O}_{10} \ldots \mathrm{Cu}^{2+}$ at -766.554 $\mathrm{kJ} / \mathrm{mol}$ and $\mathrm{O}_{11} \ldots \mathrm{Cu}^{2+}$ at $-766.523 \mathrm{~kJ} / \mathrm{mol}$. Energy of the resulting interactions is not much different because $\ldots \mathrm{Cu}^{2+}$ interacts with $\mathrm{O}_{10}$ and $\mathrm{O}_{11}$ producing energies that are not much different. However, the stability generated from the $\mathrm{O}_{10}$ atomic interaction with $\mathrm{Cu}^{2+}$ tends to be greater because $O_{11}$ has a larger steric effect thus ...C $\mathrm{Cu}^{2+}$ interacts better with $\mathrm{O}_{10}$ (Figure 5.b) (Warren, 1981).
The interactions that occur in the EOA molecule take place in the positions of $\mathrm{O}^{10} \ldots \mathrm{Cu}^{2+}, \mathrm{O}_{11} \ldots \mathrm{Cu}^{2+}$, $\mathrm{O}_{26} \ldots \mathrm{Cu}^{2+}, \mathrm{O}_{27} \ldots \mathrm{Cu}^{2+}$ which produced energy of interactions of $-879.662 \mathrm{~kJ} / \mathrm{mol},-877.986 \mathrm{~kJ} / \mathrm{mol}$, $859.391 \mathrm{~kJ} / \mathrm{mol}$, and $-879.661 \mathrm{~kJ} / \mathrm{mol}$, respectively. Geometry optimizations of interaction structures obtained the most stable energy in the interaction of $\mathrm{O}_{10}$ EOA atom with ....... ${ }^{2+}$ as it has the greatest interaction energy compared to the others (Zhai et al., 2018). This is because in that position $\mathrm{Cu}^{2+}$ interacts a lot more creating stronger interaction (Figure 6.a).

Molecular interaction positions between PMEOA and $\mathrm{Cu}^{2+}$ namely $\mathrm{O}_{10} \ldots \mathrm{Cu}^{2+}, \mathrm{O}_{11} \ldots \mathrm{Cu}^{2+}, \mathrm{O}_{26} \ldots \mathrm{Cu}^{2+}$, and $\mathrm{O}_{27} \ldots \mathrm{Cu}^{2+}$ produced interaction energies of $1042.046 \mathrm{~kJ} / \mathrm{mol}, \quad-1042.044 \mathrm{~kJ} / \mathrm{mol},-990.714$ $\mathrm{kJ} / \mathrm{mol}$, $-912.450 \mathrm{~kJ} / \mathrm{mol}$ and $-995.279 \mathrm{~kJ} / \mathrm{mol}$, respectively. The greatest interaction energy sign on the molecular geometry optimization results states stable molecular structure (Yopianto, et al., 2011). Accordingly, the most powerful interaction of the PMEOA molecule is at the position $\mathrm{O}_{10} \ldots \mathrm{Cu}^{2+}$ as it produces the greatest interaction energy (Figure 7.a).

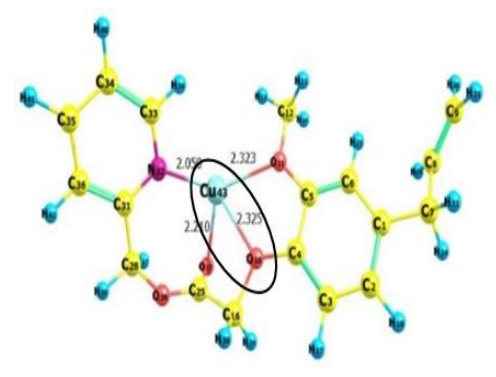

(a)

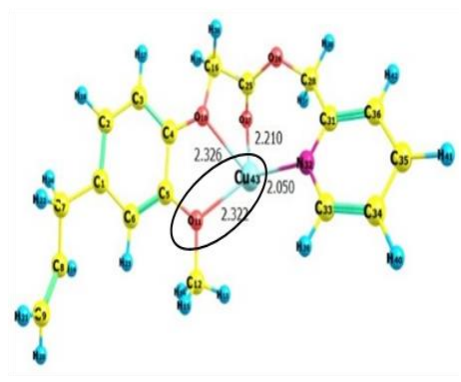

(b)

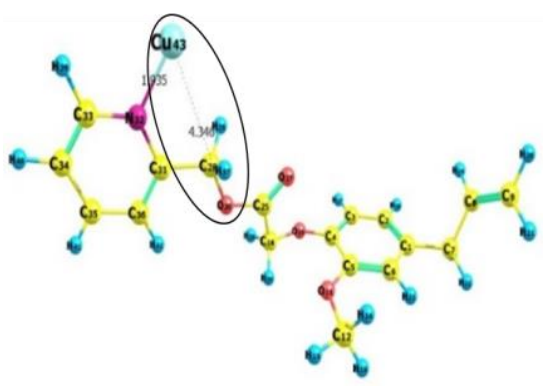

(c)

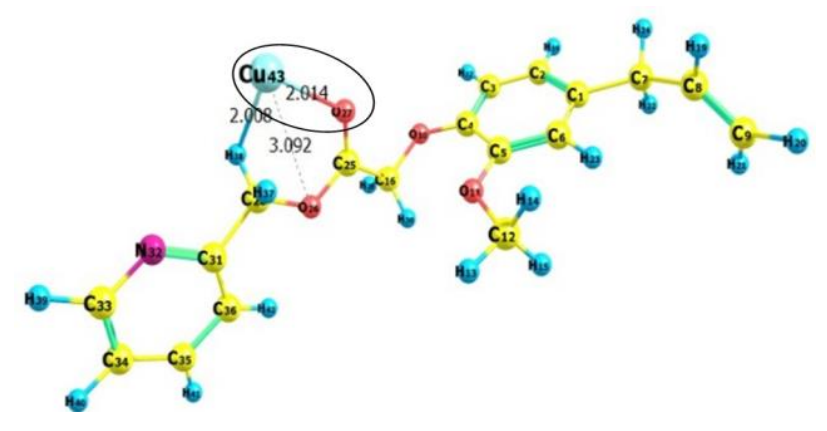

(d)

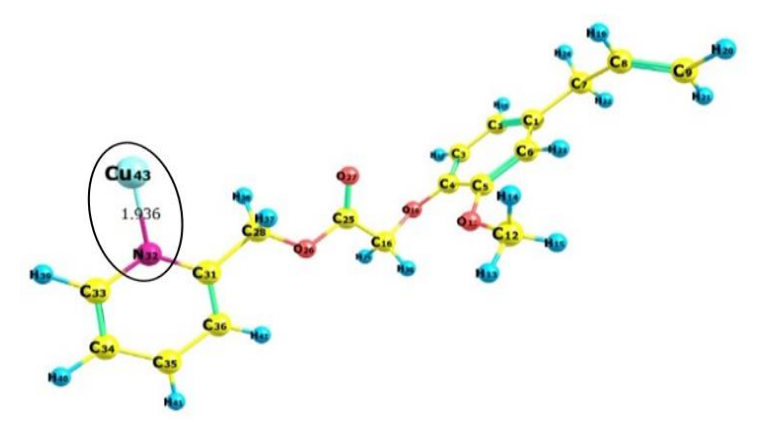

(e)

\section{$\mathrm{H} \odot \mathrm{C} \odot \mathrm{O} \odot \mathrm{N} \odot \mathrm{Cu}$}

Figure 7. Geometry optimization of pyridine methyl eugenoxy acetate (PMEOA) that has interacted with $\mathrm{Cu}^{2+}$ in positions (a) PMEOA $\mathrm{O}_{10}$ atom ....... $\mathrm{Cu}^{2+}$ (b) PMEOA $\mathrm{O}_{11}$ atom.... $\mathrm{Cu}^{2+}$ (c) $\mathrm{PMEOA} \mathrm{O}_{26}$ atom.... $\mathrm{Cu}^{2+}$ (d) $\mathrm{PMEOA} \mathrm{O}_{27}$ atom.... $\mathrm{Cu}^{2+}$ (e) $\mathrm{PMEOA} \mathrm{N}_{32}$ atom $\ldots \mathrm{Cu}^{2+}$ 
Molekul, Vol. 14. No. 2, November 2019: 149 - 156

Table 1. Bond length, angle, and energy obtained from geometry optimization of molecular interaction structure.

\begin{tabular}{ccrcrc}
\hline Complexes & Bond length & \multicolumn{1}{c}{$(\AA)$} & \multicolumn{1}{l}{ Bond angle } & \multicolumn{1}{c}{ Degree } & Energy $(\mathrm{kJ} / \mathrm{mol})$ \\
\hline \multirow{2}{*}{ Eugenol } & $\mathrm{Cu}_{25} \ldots \mathrm{O}_{10}$ & 2.04774 & $\mathrm{C}_{4}-\mathrm{O}_{10} \ldots \mathrm{Cu}_{25}$ & 113.57918 & -766.554 \\
& $\mathrm{Cu}_{25} \ldots \mathrm{O}_{11}$ & 2.0613 & $\mathrm{C}_{5}-\mathrm{O}_{11} \ldots \mathrm{Cu}_{25}$ & 113.68029 & -766.523 \\
\hline \multirow{4}{*}{ EOA } & $\mathrm{Cu}_{31} \ldots \mathrm{O}_{10}$ & 2.19375 & $\mathrm{C}_{4}-\mathrm{O}_{10} \ldots \mathrm{Cu}_{31}$ & 115.13062 & -879.662 \\
& $\mathrm{Cu}_{31} \ldots \mathrm{O}_{11}$ & 2.14228 & $\mathrm{C}_{5}-\mathrm{O}_{11} \ldots \mathrm{Cu}_{31}$ & 122.29807 & -877.986 \\
& $\mathrm{Cu}_{31} \ldots \mathrm{O}_{26}$ & 2.96157 & $\mathrm{C}_{25}-\mathrm{O}_{26} \ldots \mathrm{Cu}_{31}$ & 69.98086 & -859.391 \\
& $\mathrm{Cu}_{31} \ldots \mathrm{O}_{27}$ & 2.00613 & $\mathrm{C}_{25}-\mathrm{O}_{27} \ldots \mathrm{Cu}_{31}$ & 120.98512 & -879.661 \\
\hline \multirow{5}{*}{ PMEOA } & $\mathrm{Cu}_{43} \ldots \mathrm{O}_{10}$ & 2.32538 & $\mathrm{C}_{5}-\mathrm{O}_{10} \ldots \mathrm{Cu}_{43}$ & 88.73277 & -1042.046 \\
& $\mathrm{Cu}_{43} \ldots \mathrm{O}_{11}$ & 2.32166 & $\mathrm{C}_{5}-\mathrm{O}_{11} \ldots \mathrm{Cu}_{43}$ & 122.84923 & -1042.044 \\
& $\mathrm{Cu}_{43} \ldots \mathrm{O}_{26}$ & 4.34555 & $\mathrm{C}_{25}-\mathrm{O}_{26} \ldots \mathrm{Cu}_{43}$ & 115.37284 & -990.714 \\
& $\mathrm{Cu}_{43} \ldots \mathrm{O}_{27}$ & 2.0138 & $\mathrm{C}_{25}-\mathrm{O}_{27} \ldots \mathrm{Cu}_{43}$ & 122.82326 & -912.450 \\
& $\mathrm{Cu}_{43} \ldots \mathrm{N}_{32}$ & 1.935510 & $\mathrm{C}_{31}-\mathrm{N}_{32} \ldots \mathrm{Cu}_{43}$ & 121.54048 & -995.279 \\
\hline
\end{tabular}

Table 2. Comparison of bond length, angle and dihedral results from geometry optimization of molecular structure

\begin{tabular}{|c|c|c|c|c|c|c|}
\hline Molecule & $\begin{array}{l}\text { Bond } \\
\text { length }\end{array}$ & $(\AA)$ & Bond angle & Degree & Torsion Angles & Degree \\
\hline \multicolumn{7}{|l|}{ Eugenol } \\
\hline \multirow{2}{*}{ Optimization } & $\mathrm{O}_{10}-\mathrm{C}_{4}$ & 1.34861 & $\mathrm{C}_{3}-\mathrm{C}_{4}-\mathrm{O}_{10}$ & 120.1614 & $\mathrm{C}_{2}-\mathrm{C}_{3}-\mathrm{C}_{4}-\mathrm{O}_{10}$ & 179.9665 \\
\hline & $\mathrm{O}_{11}-\mathrm{C}_{5}$ & 1.35878 & $\mathrm{C}_{4}-\mathrm{C}_{5}-\mathrm{O}_{11}$ & 114.1238 & $\mathrm{C}_{3}-\mathrm{C}_{4}-\mathrm{C}_{5}-\mathrm{O}_{11}$ & 179.9422 \\
\hline \multicolumn{7}{|l|}{ Interaction } \\
\hline Configuration 1 & $\mathrm{O}_{10}-\mathrm{C}_{4}$ & 1.36927 & $\mathrm{C}_{3}-\mathrm{C}_{4}-\mathrm{O}_{10}$ & 122.3264 & $\mathrm{C}_{2}-\mathrm{C}_{3}-\mathrm{C}_{4}-\mathrm{O}_{10}$ & -179.273 \\
\hline Configuration 2 & $\mathrm{O}_{11}-\mathrm{C}_{5}$ & 1.36581 & $\mathrm{C}_{4}-\mathrm{C}_{5}-\mathrm{O}_{11}$ & 116.2912 & $\mathrm{C}_{3}-\mathrm{C}_{4}-\mathrm{C}_{5}-\mathrm{O}_{11}$ & -179.408 \\
\hline \multicolumn{7}{|l|}{$\mathrm{EOA}$} \\
\hline \multirow[t]{4}{*}{ Optimization } & $\mathrm{O}_{10}-\mathrm{C}_{4}$ & 1.36849 & $\mathrm{C}_{3}-\mathrm{C}_{4}-\mathrm{O}_{10}$ & 120.0898 & $\mathrm{C}_{2}-\mathrm{C}_{3}-\mathrm{C}_{4}-\mathrm{O}_{10}$ & -176.416 \\
\hline & $\mathrm{O}_{11}-\mathrm{C}_{5}$ & 1.35068 & $\mathrm{C}_{4}-\mathrm{C}_{5}-\mathrm{O}_{11}$ & 115.9893 & $\mathrm{C}_{3}-\mathrm{C}_{4}-\mathrm{C}_{5}-\mathrm{O}_{11}$ & 179.6043 \\
\hline & $\mathrm{O}_{26}-\mathrm{C}_{25}$ & 1.33661 & $\mathrm{C}_{16}-\mathrm{C}_{25}-\mathrm{O}_{27}$ & 113.7281 & $\mathrm{O}_{10}-\mathrm{C}_{16}-\mathrm{C}_{25}-\mathrm{O}_{27}$ & 179.4115 \\
\hline & $\mathrm{O}_{27}-\mathrm{C}_{25}$ & 1.17834 & $\mathrm{C}_{16}-\mathrm{C}_{25}-\mathrm{O}_{27}$ & 125.3131 & $\mathrm{O}_{10}-\mathrm{C}_{16}-\mathrm{C}_{25}-\mathrm{O}_{27}$ & -0.00411 \\
\hline \multicolumn{7}{|l|}{ Interaction } \\
\hline Configuration 1 & $\mathrm{O}_{10}-\mathrm{C}_{4}$ & 1.35951 & $\mathrm{C}_{3}-\mathrm{C}_{4}-\mathrm{O}_{10}$ & 124.1649 & $\mathrm{C}_{2}-\mathrm{C}_{3}-\mathrm{C}_{4}-\mathrm{O}_{10}$ & 179.0462 \\
\hline Configuration 2 & $\mathrm{O}_{11}-\mathrm{C}_{5}$ & 1.32628 & $\mathrm{C}_{4}-\mathrm{C}_{5}-\mathrm{O}_{11}$ & 114.8564 & $\mathrm{C}_{3}-\mathrm{C}_{4}-\mathrm{C}_{5}-\mathrm{O}_{11}$ & -179.701 \\
\hline Configuration 3 & $\mathrm{O}_{26}-\mathrm{C}_{25}$ & 1.30246 & $\mathrm{C}_{16}-\mathrm{C}_{25}-\mathrm{O}_{27}$ & 116.9226 & $\mathrm{O}_{10}-\mathrm{C}_{16}-\mathrm{C}_{25}-\mathrm{O}_{27}$ & -179.976 \\
\hline Configuration 4 & $\mathrm{O}_{27}-\mathrm{C}_{25}$ & 1.19695 & $\mathrm{C}_{16}-\mathrm{C}_{25}-\mathrm{O}_{27}$ & 121.7505 & $\mathrm{O}_{10}-\mathrm{C}_{16}-\mathrm{C}_{25}-\mathrm{O}_{27}$ & -6.13855 \\
\hline \multicolumn{7}{|l|}{ PMEOA } \\
\hline \multirow[t]{5}{*}{ Optimization } & $\mathrm{O}_{10}-\mathrm{C}_{4}$ & 1.36678 & $\mathrm{C}_{3}-\mathrm{C}_{4}-\mathrm{O}_{10}$ & 120.0927 & $\mathrm{C}_{2}-\mathrm{C}_{3}-\mathrm{C}_{4}-\mathrm{O}_{10}$ & -176.327 \\
\hline & $\mathrm{O}_{11}-\mathrm{C}_{5}$ & 1.34967 & $\mathrm{C}_{4}-\mathrm{C}_{5}-\mathrm{O}_{11}$ & 115.9279 & $\mathrm{C}_{3}-\mathrm{C}_{4}-\mathrm{C}_{5}-\mathrm{O}_{11}$ & -179.991 \\
\hline & $\mathrm{O}_{26}-\mathrm{C}_{25}$ & 1.33915 & $\mathrm{C}_{16}-\mathrm{C}_{25}-\mathrm{O}_{27}$ & 117.1841 & $\mathrm{O}_{10}-\mathrm{C}_{16}-\mathrm{C}_{25}-\mathrm{O}_{27}$ & 178.6205 \\
\hline & $\mathrm{O}_{27}-\mathrm{C}_{25}$ & 1.18047 & $\mathrm{C}_{16}-\mathrm{C}_{25}-\mathrm{O}_{27}$ & 123.6502 & $\mathrm{O}_{10}-\mathrm{C}_{16}-\mathrm{C}_{25}-\mathrm{O}_{27}$ & 0,55763 \\
\hline & $\mathrm{N}_{32}-\mathrm{C}_{31}$ & 1.32213 & $\mathrm{C}_{28}-\mathrm{C}_{31}-\mathrm{N}_{32}$ & 114.7156 & $\mathrm{O}_{26}-\mathrm{C}_{28}-\mathrm{C}_{31}-\mathrm{N}_{32}$ & $-159,967$ \\
\hline \multicolumn{7}{|l|}{ Interaction } \\
\hline Configuration 1 & $\mathrm{O}_{10}-\mathrm{C}_{4}$ & 1.30288 & $\mathrm{C}_{3}-\mathrm{C}_{4}-\mathrm{O}_{10}$ & 126.0435 & $\mathrm{C}_{2}-\mathrm{C}_{3}-\mathrm{C}_{4}-\mathrm{O}_{10}$ & -179.452 \\
\hline Configuration 2 & $\mathrm{O}_{11}-\mathrm{C}_{5}$ & 1.32027 & $\mathrm{C}_{4}-\mathrm{C}_{5}-\mathrm{O}_{11}$ & 114.2208 & $\mathrm{C}_{3}-\mathrm{C}_{4}-\mathrm{C}_{5}-\mathrm{O}_{11}$ & 179.0307 \\
\hline Configuration 3 & $\mathrm{O}_{26}-\mathrm{C}_{25}$ & 1.32519 & $\mathrm{C}_{16}-\mathrm{C}_{25}-\mathrm{O}_{27}$ & 110.3717 & $\mathrm{O}_{10}-\mathrm{C}_{16}-\mathrm{C}_{25}-\mathrm{O}_{27}$ & 163.4247 \\
\hline Configuration 4 & $\mathrm{O}_{27}-\mathrm{C}_{25}$ & 1.20661 & $\mathrm{C}_{16}-\mathrm{C}_{25}-\mathrm{O}_{27}$ & 124.4902 & $\mathrm{O}_{10}-\mathrm{C}_{16}-\mathrm{C}_{25}-\mathrm{O}_{27}$ & -3.36745 \\
\hline Configuration 5 & $\mathrm{~N}_{32}-\mathrm{C}_{31}$ & 1.33613 & $\mathrm{C}_{28}-\mathrm{C}_{31}-\mathrm{N}_{32}$ & 113.6548 & $\mathrm{O}_{26}-\mathrm{C}_{28}-\mathrm{C}_{31}-\mathrm{N}_{32}$ & -166.615 \\
\hline
\end{tabular}


Tabel 3. Energy Optimization of molecular structure with interactions of molecules and without molecular interactions

\begin{tabular}{lllllll}
\hline \multirow{2}{*}{ Molecule } & \multicolumn{5}{c}{ Energy $(\mathrm{kJ} / \mathrm{mol})$} \\
\cline { 2 - 7 } & Configuration 1 & Configuration 2 & Configuration 3 & Configuration 4 Configuration 5 & Optimization \\
\hline Eugenol & -5706420.41 & -5706420.379 & & & & -5705653.856 \\
EOA & -6301540.971 & -6301539.295 & -6301520.701 & -6301540.971 & & -6300661.31 \\
PMEOA & -7048798.877 & -7048845.643 & -7048845.642 & -7048794.311 & -7048716.047 & -7047803.598 \\
\hline
\end{tabular}

As a result of the interaction, there is a change in the geometrical structure of the molecules. The changes can include the dihedral angle and the energy. The results of the calculations are presented in Table 3 where the molecules that had been interacted with $\mathrm{Cu}^{2+}$ are more stable than the molecules that had not. This is demonstrated by the energy produced by the $\mathrm{Cu}^{2+}$-interacting molecules that is lower than the molecules that have not been interacted with $\mathrm{Cu}^{2+}$. In particular, the most stable molecule was the PMEOA $\mathrm{Cu}_{43} \ldots \mathrm{O}_{10}$ molecule with the lowest energy produced compared to the other molecules is shown in Table 3.

\section{CONCLUSIONS}

This study has confirmed the experimental results of the extraction of $\mathrm{Cu}$ metal ion with eugenol and its derivatives (EOA, PMEOA) with computational studies. Experimental results of eugenol and synthesis of eugenol derivatives in the form of EOA and PMEOA were applied to extract $\mathrm{Cu}^{2+}$. Empirically the PMEOA was the best in extracting $\mathrm{Cu}^{2+}$ exceeding eugenol and EOA proven by the percentage of $\mathrm{Cu}^{2+}$ extracted in PMEOA, EOA and eugenol at $78.76 \%, 0.62 \%$, and $0 \%$ respectively. Experimental results are supported by computational studies in which the most negative interaction energy generated comes from the PMEOA molecule. Thus it can be concluded that PMEOA is the most stable molecule in creating interaction with $\mathrm{Cu}^{2+}$.

\section{REFERENCES}

Djunaidi, M. C., Jumina, Siswanta, D., \& Ulbricht, $M$. (2015): Synthesis of fe ionic-imprinted polyeugenol using polyethylene glycol diglycidilether as cross-linking agent for sorption of fe(III). Indonesian Journal of Chemistry, 15(3), 305-314. https://doi.org/10.22146/ijc.21200

Djunaidi, M. C., Khabibi, \& Khrisna, D. (2010): Sintesis Asam Eugenoksi Asetat (EOA) dari Eugenol untuk Ekstraksi Logam Berat dan Recovery Krom dari Limbah Elektroplating. Jska, 13(II), 12-17.

Diunaidi, M. C., Siswanta, D., \& Jumina. (2015): Elvent influences on synthesis of $\mathrm{Fe}$ (III)-imprinted polyeugenol using polyethylene glycol diglycidilether (PEGDE) as cross-linking agent and its application as $\mathrm{Fe}$ (III) sorbent. Oriental Journal of Chemistry, 31(4), 2223-2229. https://doi.org/10.13005/ojc/310447

Diunaidi, M. C., Wibawa, P. J., \& Murti, R. H. (2018): Synthesis of A Novel Carrier Compound Thiazoethyl Methyl Eugenoxyacetate from Eugenol and Its Use in the Bulk Liquid Membrane Technique. Indonesian Journal of Chemistry, 18(1), 121. https://doi.org/10.22146/iic.25075

Hamzah, B., Jalaluddin, N., Wahab, A. W., Upe, A., Keguruan, F., Tadulako, U.,Hasanuddin, U. (2011): Pengaruh lon Kadmium ( II ) dan Nikel ( II ) pada Ekstraksi lon Tembaga ( II ) dengan Ekstraktan 4-Benzoil -1-Fenil-3-Metil- 2Pirazolin-5-On Menggunakan Emulsi Membran Cair, 13(65), 269-275.

Harimu, L., Matsjeh, S., Siswanta, D., \& Santosa, J. (2009): Polieugenoxiacetate Synthesis as a Carrier for Separation of Heavy Metal ion Fe (II), $\mathrm{Ni}$ (II), $\mathrm{Cr}$ (III), Ni (II), Co (II) Using the Extraction Method. Indones. J. of Chem., 9(2), 261-266.

Ho, T. L. (1975): The Hard Soft Acids Bases (HSAB) Principle and Organic Chemistry. Chemical Reviews, 75(1), 1-20. https://doi.org/10.1021/cr60293a001

Kakoi, T., Toh, T., Kubota, F., Goto, M., Shinkai, S., \& Nakashio, F. (1998): Liquid-Liquid Extraction of Metal lons with a Cyclic Ligand Calixarene Carboxyl Derivative. Analytical Sciences, 14(3), 501-506.

https://doi.org/10.2116/analsci.14.501

Khoutoul, M., Lamsayah, M., Al-Blewi, F. F., Rezki, N., Aouad, M. R., Mouslim, M., \& Touzani, R. (2016): Liquid-liquid extraction of metal ions, DFT and TD-DFT analysis of some 1,2,4-triazole Schiff Bases with high selectivity for $\mathrm{Pb}$ (II) and $\mathrm{Fe}(\mathrm{II})$. Journal of Molecular Structure, 1113, 99107. https://doi.org/10.1016/j.molstruc.2016.02.04 6

Kundari, N. A., \& Slamet, W. (2008):Tinjauan kesetimbangan adsorpsi tembaga dalam limbah pencuci pcb dengan zeolit. Seminar Nasional IV SDM Teknologi Nuklir, 25 - 26 Agustus 2008, 19, 489-496.

Mirwan, A., \& Wicakso, D. R. (2008): Pengaruh Isian Jenis Bola Kaca terhadap Dinamika Tetes dan 
Koefisien Pindah Massa Ekstraksi Cair-Cair dalam Kolom Isian. Info Teknik (Fakultas Teknik Unlam Banjarmasing), 9(2), 112-116.

Sneddon, J. (1997): Encyclopedia of Common Natural Ingredients Used in Food, Drugs, and Cosmetics, 2nd ed. Microchemical Journal (Vol. 55). https://doi.org/10.1006/mchi.1996.1388

Warren, S. (1981): ORGANIC SYNTHESIS: The Disconnection Approach. Lecturer, Departement of Chemistry University of Cambridge and Fellow of Churchill Collage University of Cambridge
Yopianto, D., Marta J. Sipangkar, Rikno B., Parsaoran S., (2011): Study Interaction between Dimin Chitin Segments and Molecules, Journal of Chemical Science and Applications, 14 (2), 4347.

Zhai, C., Hou, B., Peng, P., Zhang, P., Li, L., \& Chen, $X$. (2018): Hydrogen bonding interaction of ascorbic acid with nicotinamide: Experimental and theoretical study. Journal of Molecular Liquids, 249, 9-15. https://doi.org/10.1016/j.molliq.2017.11.034 